\title{
Author Correction: Genome expansion and lineage-specific genetic innovations in the forest pathogenic fungi Armillaria
}

György Sipos, Arun N. Prasanna, Mathias C. Walter, Eoin O'Connor, Balázs Bálint, Krisztina Krizsán, Brigitta Kiss, Jaqueline Hess, Torda Varga, Jason Slot, Robert Riley, Bettina Bóka, Daniel Rigling, Kerrie Barry, Juna Lee, Sirma Mihaltcheva, Kurt LaButti, Anna Lipzen, Rose Waldron, Nicola M. Moloney, Christoph Sperisen, László Kredics, Csaba Vágvölgyi, Andrea Patrignani, David Fitzpatrick, István Nagy, Sean Doyle, James B. Anderson, Igor V. Grigoriev, Ulrich Güldener, Martin Münsterkötter and László G. Nagy

Correction to: Nature Ecology \& Evolution https://doi.org/10.1038/s41559-017-0347-8, published online 30 October 2017.

In the version of this Article originally published, it was incorrectly stated that " 16,687 protein-coding genes were inferred for the most recent common ancestor (MRCA) of Armillaria"; the value was incorrect and it should have read " 15,787 ". This has now been corrected.

Published online: 9 February 2018

https://doi.org/10.1038/s41559-018-0469-7 